UDC 81'23

doi: 10.22250/2410-7190_2021_7_1_5_12

\author{
Asmik A. Avagyan \\ Russian State University of Tourism and Service, \\ Peoples' Friendship University of Russia \\ Moscow, Russian Federation \\ avagyanasmik@gmail.com
}

\author{
Magomed G. Gazilov, Marina R. Gozalova \\ Russian State University of Tourism and Service \\ Moscow, Russian Federation \\ mag.wizard@yandex.ru,mgozalova@mail.ru
}

\title{
Language as a form of expressing the national identity: A Russian national character in proverbs
}

\begin{abstract}
The present article contains the results of an analysis of Russian proverbs reflecting some of the most popular traits of character stereotypically attributed to Russian people. The research methodology includes several stages: a selection of 400 Russian proverbs and sayings illustrating different aspects of a Russian national character, a quantitative analysis of data collected, and thematic grouping of 30 proverbs most explicitly pointing to popular stereotypes about Russian people. The theoretical part of the article comprises the definitions of such key concepts as 'nation', 'nationality', 'ethnicity', 'national, civil and ethnic identity', which have been analyzed with reference to other researchers working in this field. The research results have shown that the most popular human qualities of Russian people are religiousness, patience and firmness, diligence and talent, a love for freedom, a will-power and courage, hospitality, generosity and breadth of soul.
\end{abstract}

Keywords: national identity, nation, the Russian language, national character, proverbs, sayings.

(C) Avagyan A. A., Gazilov M. G., Gozalova M. R. 2021

For citation: Avagyan, A. A., Gazilov, M. G., Gozalova, M. R. (2021). Language as a form of expressing the national identity: A Russian national character in proverbs. Teoreticheskaya i prikladnaya lingvistika [Theoretical and Applied Linguistics], 7 (1), 5-12. doi: 10.22250/2410-7190_2021_7_1_5_12.

\section{Introduction}

Russia is a large country with a diverse ethnic population. Since the notion of national identity is especially relevant to multinational countries, Russia has always been a focus of special attention. For a deeper understanding of the concept and components of a national identity which can be considered to be a part of culture, we have to deal with verbal means of communication and analyze them. This is due to the close connection of language and culture.

Language is often the first thing people face when learning Russian culture or visiting Russia. For this reason, it seems important to show how language reflects the national identity. This will help both language learners in understanding the 'mysterious Russian soul' and native speakers in assessing the amount of linguistic heritage which may serve as a basis for future research in this field.

The present article gives some insight into recent research which aimed to find out the most popular traits of a Russian national character frequently appearing in Russian proverbs. They often have a purely national origin, and to make them internationally understandable, in this research they have been accompanied by author's translation into English. This has been 
done in order to demonstrate the stylistics of original sentences which might differ in their English equivalents. After the selection process they have been thematically grouped according to national characteristics they reflect. It is assumed that almost any expectation or stereotype about representatives of a particular nation can be found in their language. The Russian language is not an exception: widely known as one of the richest languages in the world, it has a huge number of proverbs which have made a long way from one generation to another and reached our days.

\section{A definition of national identity}

The term 'identity' is defined by contemporary researchers in many different ways. Obviously, there are even more approaches to defining the term 'national identity' which is rather unambiguous. This paper is based on the following definition of national identity: "a realization of identity, a self-defined categorization of a person as a member of a particular ethnic group" [Zheltova, 2003, p. 16]. As we can see, national identity is a reflection of ethnic affiliation which can be viewed both as a pre-defined (in-born) feature and as a matter of one's self-categorization. In a broader sense, we can also interpret the word self-defined as 'defined by the nation as a whole'. Nevertheless, whatever the interpretation of this word is, the above-mentioned definition explicitly points to the fact that natsional'nost' 'nationality' and etnichnost' 'ethnicity' can be interchangeably used in Russian as full synonyms. In contrast, the English terms are clearly distinguished, and the first meaning of 'nationality' in Oxford Dictionary is "the status of belonging to a particular nation" [Lexico, 2020], i.e. citizenship, political affiliation while 'ethnicity' is defined as "the fact or state of belonging to a social group that has a common national or cultural tradition" [Lexico, 2020].

It is to be noted that national identity is not the same as civil identity. The term 'national identity' is used to refer to "a sense of a nation as a cohesive whole, as represented by distinctive traditions, culture, and language" [Lexico, 2020]. Civil identity is usually based on identification with a particular society and a state in general. This term rarely appears in English dictionaries and has the following definition: "the awareness of a person of belonging to a community of citizens of a particular state having a certain personal meaning" [Sotsiologiya, 2020]. Furthermore, national identity (or national self-realization) is not always the same as ethnic identity. The latter is defined as "an individual's feeling of belonging to a particular ethnic group" [Encyclopedia.com, 2019] while in a multinational country, 'a national identity' as a broad term may also include a few ethnicities. For example, the word Russian is sometimes applied to Bashkirs, Tatars and other ethnic groups sharing the same geographic area within the country.

\section{A definition of nation}

For a better understanding of the concept of national identity, the term 'nation' needs to be defined. In one of his works, E. Rénan, a famous French philosopher, gives the following definition: "A nation is a soul, a spiritual principle. Two things, which in truth are but one, constitute this soul or spiritual principle. One lies in the past, one in the present. One is the possession in common of a rich legacy of memories; the other is present-day consent, the desire to live together, the will to perpetuate the value of the heritage that one has received in an undivided form" [Rénan, 1887, p.306]. In this definition, a nation is presented from the philosophical viewpoint and is assumed to serve as a bridge connecting the past and the present. Indeed, nations do not appear in a short period, it does take a long period of history for any group of people to be classified as a nation. Throughout this period, people sharing the same territory, language, and culture contribute to their nation's history and become a part of it.

Another French researcher G. Noiriel in his paper "À quoi sert l'identité nationale?" ('What does a national identity serve to?') points to the fact that the term 'nation' 
is rather unambiguous. He synonymizes such concepts as equity ('la mêmeté') and individuality ('l'ipséité'). He notes that equity points to a linguistic unity of all members of a nation (all of them speak French). At the same time, the term 'individuality' emphasizes the common historic background and specific traditions of a French nation and therefore supports a sense of belonging to it [Noiriel, 2007, p. 46]. This is also true in case of the Russian word natsia 'nation'. If it is analyzed in relation to other nations, then a comparative analysis takes place showing what distinguishes this nation from others nations or what special features it has. Obviously, in this case language becomes a central feature. However, if nation is analyzed as a whole, then its components (primarily cultural) become the object of analysis. Although there is no explicit link between equity and individuality, we can conclude that they both constitute the term 'nation'.

In 2016, French politicians E. Delbecque and S. Richard in their interview to "Le Figaro" newspaper stated that a national identity was the basis which helped nations to do their best for successful development of their country. These researchers identified the nucleus of a French national and cultural identity. This includes the French language which has one of the most important functions: the function of realization and accepting one's national identity [Delbecque, Richard, 2016].

Russian researchers have also been interested in the concept of a national identity for a long time. We adopt the idea of national identity worked out by [Smirnova, Kiselev, 2006] who contributed to the concept of a multiple identity. It is used when an individual identifies himself or herself not only with one nation. If a society member is attracted by a culture of another nation and (s)he is ready to share it with other representatives, then this society member realizes his/her multiple identity [Smirnova, Kiselev, 2006, p. 12]. Multiple identities are often the case of Russian residents, especially those who live in large cities attracting a lot of international newcomers. In terms of everyday international and intercultural communication and intensive language contacts people might question their former national identities and may be exposed to strong influence of new cultures and partially or fully adopt them. In these cases, language as an integral part of any culture is adopted, too.

The analysis of a multiple identity can also be found in works of Professor V. N. Badmaev. He assumes that there are not only personal and social identities but also territorial, national, cultural, civil and religious identities [Badmaev, 2005, p. 71]. They can be treated as separate types of identities or as different facets of the same identity classified as a multiple one.

Vladimir V. Pozner, a famous journalist and TV reporter, states that "there is nothing more difficult and pointless than attempts to determine external and internal traits typical for a particular nation" [Pozner, 2015, p. 43]. He was born in France, spent his childhood in Russia and now works in Russia still trying to identify himself. In his book "Their Italy", he writes the following: "Can we say that hospitality is one of the traits typical for Russians? Yes, we can. And can we say that hospitality is one of the traits typical for Georgians? Yes, of course. But does it mean that Russians and Georgians are alike?" [Pozner, 2015, p. 43].

There is a terminological difficulty which inevitably occurs when thinking about Russia. It has to do with words russkiy and rossiyskiy which have one English equivalent 'Russian'. Despite this, one of the greatest Russian-speaking people Alexander S. Pushkin who made a significant contribution into the formation of the Russian language often used these two words as full synonyms. However, in this article, we make a distinction between these terms: russkie means one ethnicity (nation) while rossiyane means several ethnicities (nations) within Russia.As in English, there is no such distinction in the French language: the word les Français (French) means both a nation and a nationality (citizenship). Furthermore, despite being representatives of different nationalities all Russian citizens are usually called russkie ('Russians') in many other languages. For example, there is a concept les Russes (Russians) in French which can be translated into Russian by two different words: russkie or 
rossiyane. Obviously, this is due to the fact that this word has a meaning which contains a 'nation-making' component. Interestingly, in the Russian language, there had been no difference between the two terms under discussion until the 20th century. Thus, these concepts had no verbal distinction. It could have resulted from the difference in spelling of the country's name: Rus' / Rossiya.

With its special geographic location and a combination of traits typical for both western and eastern civilizations, Russia has always been a matter of great interest. Nowadays we can notice a growing interest to a national character of the Russian people. In our opinion, this character is reflected in philosophy, art and language which is the best and the brightest expression of national characteristic features. Considering the fact that Russian is, first of all, a language of the Russian people and a means of expressing the Russian national and cultural identity, we aim to present some examples of verbal means of expressing the Russian national identity.

\section{The Russian national character}

The term 'national character' has not yet been unanimously accepted by contemporary scholars. Despite this fact, the majority of them widely agree that there are certain specific codes of behaviour typical for a particular nation. However, this term should not be mixed up with 'mentality' which is defined by I. A. Sternin and his school as "a specific way of perception and understanding of reality determined by a set of cognitive stereotypes of conscious characteristics of a certain group of people" [Sternin et al., 2003, p. 24-26]. As we can see, mentality characterizes not only the nation as a whole but also different social groups of people. For this reason, we will apply the term 'national character' which seems broader and presents the most popular traits of character often associated by foreigners and locals with Russian people.

'A mysterious Russian soul' has been formed under particular historical circumstances being also influenced by a geographic location of the country, its climate and religion. Russians are commonly viewed as exceptionally patient people. They keep patience till last moment, but finally they explode. As Alexander A. Pushkin wrote: "God save us from seeing a Russian revolt, senseless and merciless".

Russians also tend to be dreamy or even a bit gloomy. It may be connected with severe climate, long cold winter and the lack of sunlight for almost half of the year. Moreover, Russian people consciously bring close the concepts of smile and laugh: 'A laugh for no reason is a sign of foolishness', as a popular Russian saying goes.

Additionally, many people think that Russians have such qualities as self-humiliation and underestimation of their merits. They may be connected with an orthodox rule saying that pride is one of the 7 deadly sins that destruct your immortal soul.

\section{Russian proverbs}

The secrets of a Russian national character could be better understood through Russian proverbs and sayings. Although these terms are often used interchangeably, we will try to make a distinction between them in order to select one type of set expressions subject to further analysis. In this paper, a saying is understood more broadly - as a well-known expression, something that has been said in the past and has become popular being often repeated by common people. In contrast, a proverb is a type of saying containing a wise thought, a piece of advice or a universal value. This distinction is critical for this research which focuses only on proverbs, as they contain deeper ideas expressed more explicitly than sayings. Although Russian phraseology has always been a popular field of study, there are still a lot of understudied aspects in the connection of language and culture subject to 
research. This study of proverbs aims to cover one of such aspects and present the results of quantitative analysis showing a relationship between language and national character.

Language is a mirror which reflects not only a real surrounding world of a person but also his/her mentality, representations of peoples about themselves and their picture of the world [Makarova et al., 2018, p. 618]. To see this reflection of a language, we have analyzed about 400 Russian proverbs from one of the largest collections titled "Proverbs and sayings of the Russian people" by V.I. Dal [Dal', 2000]. From those 400 units, 30 most typical (frequent) ones were selected. In our opinion, the chosen proverbs reflect the most popular traits stereotypically attributed to the Russian character. All of them are accompanied by authors' translation into English.

They were arranged in 6 groups in accordance with different aspects of Russian national character that they reflect.

Group 1: Religiousness (8 units): Жить - Богу служить ('To live is to serve God'), Божья рука - владыка ('God's hand is a lord'), Никто не может, так Бог поможет ('Nobody can help, so God will help'), С Богом пойдёшь, до блага дойдёшь ('If you go with God, you will reach good'), У Бога милости много ('God has much favour'), Бог на милость не убог ('God isn't poor on favour'), Любящих и Бог любит ('God loves those who love God'), Бог полюбит, так не погубит ('If God will love, He won't ruin');

Group 2: Patience and firmness (7 units): Терпение - лучще спасенья ('Patience is better than rescue'), Терпение даст умение ('Patience will bring ability'), На хотенье есть терпение ('If you have a will, have patience'), Век живи, век надейся ('Live and hope'), Час терпеть, а век жить ('Suffer an hour and live for an age'), Терпя, в люди выходят ('Patient people make their way in life'), Бог даст день, даст и пищу ('God will give the day, God will give us food');

Group 3: Diligence and talent (5 units): Счастье и труд рядом живут ('Happiness and labour live nearby'), Терпение и труд все перетрут ('Patience and labour will do everything'), Золото познаётся в огне, а человек - в труде ('Gold is assessed in fire and a human - in his labour'), Талант без труда не стоит и гроша ('Talent is worth nothing without labour'), Кто рано встаёт, тому бог даёт ('Those who wake up early are blessed by God');

Group 4: Love for freedom (5 units): Хоть тяжёлая доля, да всё своя воля ('Though a heavy share, but my will for everything'), Своя воля дороже всего ('Му оwn will is the dearest'), Вольность всего дороже ('The liberty is the dearest'), Воля птичке дороже золотой клетки ('The will to a birdie is dearer than a gold cage'), Своя рука владыкка ('My hand is my lord');

Group 5: Will-power and courage (3 units): Лучше смерть в бою, чем позор в строю ('Better death in a fight than disgrace in order'), Либо полковник, либо покойник ('Either a colonel or a deceased'), Волков бояться - в лес не ходить ('Tо be afraid of wolves means not to enter a forest');

Group 6: Hospitality, generosity and breadth of soul (2 units): Хоть не богат, а гостям рад ('Though I am not rich, but glad to the guests'), Коли есть, что в печи, все на стол мечи! ('If there's something in the furnace, put everything on the table!').

Judging by the number of proverbs in each group, we can conclude that the most popular traits of the Russian character are religiousness, patience and firmness. Other human qualities commonly attributed to Russians include kindness, compassion, adventurousness and straightforwardness.

As we can see, many popular stereotypes and widely accepted traits of a Russian national character find their reflection in the language. In proverbs, these traits of a national character are often stressed in a very explicit way. If we thoroughly look through all these expressions, we will find at least two language tendencies often typical for Russian phraseology: numerous repetitions of the keywords explicitly pointing to national traits and a frequent use of 
either imperatives or nouns which are evident in proverbs on such traits as a will-power and courage. Some other popular phenomena include rhyme and rhythm which allow both native speakers and Russian language learners to recall any set expression simply repeating its rhythmic structure. Furthermore, these six most frequently stressed national character traits are very likely to match popular representations of Russian people by foreigners or, in other words, meet their expectations before they first come across with a new nation.

\section{Conclusion}

The Russian language is rich with many other set expressions that can be further classified thematically into different groups. Many of them could be borrowed from one language into another, and even a thorough etymological analysis may not lead us to the original source of a particular proverb. Obviously, most of them proclaim human qualities not only reflecting folk wisdom but also focusing on universal values. In this regard, we can conclude that not all of them necessarily show a reflection of everyday behaviour typical for Russian people. Certainly, they should be treated as a means of expressing national identity, but a lot depends on an individual and his / her own (personal) mentality and worldviews. Therefore, it is the language that, above all, contributes to the sense of national identity. It demonstrates characteristic features of people, their lifestyle and a system of values. Indeed, the Russian language is a mirror of Russian identity, and one of the most obvious verbal means of reflecting the national identity is presented by proverbs pointing to the key traits of a nation.

The current study enabled to group Russian proverbs according to the traits they demonstrate and discover the largest groups depending on the number of units included in the group. The quantitative analysis has shown that the most popular traits of Russian national character are religiousness, patience and firmness, diligence and talent, love for freedom, will-power and courage, hospitality, generosity and breadth of soul.

This research contributed to deeper understanding of the fact that language is inseparable from national character and its perception by representatives of other nations (ethnicities). However, proverbs should not encourage to make sweeping generalizations and apply any linguistic unit or set expression to all members of a Russian society. They help to understand them but still imply that there is a space for developing one's own identity which can be extremely complex, multiple and depend on one's own social background or specific worldviews, traits and models of behaviour.

Representatives of other nations can also feel comfortable in Russian culture due to the language. Good knowledge of Russian phraseology which indicates effective acquisition of the Russian language contributes to deep integration of other ethnic groups into the Russian society. Language as a marker of a national identity helps language learners to understand and realize their own identities and the national identity of representatives of other countries. It contributes to forming positive attitudes towards their own nation and other nations, a sense of civil patriotism and a love for their country.

Further research might focus on linguistic analysis of proverbs from lexical or syntactic points of view and could include a comparative analysis of Russian and English (or another language) as a form of expressing national identity. Another possible research direction might employ quantitative analysis based on the frequency of set expressions included into the Russian National corpora and appearing in different genres.

\section{References}

Badmaev, V. N. (2005). Fenomen natsional'noi identichnosti (sotsio-filosofskii analiz) [A Phenomenon of a national identity (social and philosophical analysis)]. Volgograd, Elista: Kalmyk Institute of Socioeconomic and Law Research Press. (In Russian). 
Dal', V. I. (2000). Poslovitsy i pogovorki russkogo naroda [Proverbs and Sayings of the Russian people]. Moscow : Eksmo-Press. (In Russian).

Delbecque, E., Richard, S. (2016). L'identité nationale, tout le monde en parle, mais qu'est-ce que c'est? Le Figaro. URL: <http://www.lefigaro.fr/vox/politique/2016/10/11/31001-20161011ARTFIG00305-1identite-nationale-tout-le-monde-en-parle-mais-qu-est-ce-que-c-est.php>.

Kiselev, I. Yu., Smirnova, A. G. (2006). Dinamika obraza gosudarstva $v$ mezhdunarodnykh otnosheniyakh [Dynamics of a country's image in international relations]. St Petersburg: St Petersburg State University Press. (In Russian).

Makarova, A. I., Gazilov, M. G., Gozalova, M. R. (2018). The issue of unity and diversity of linguistic worldview (on the basis of comparative research of idiomatic phrases of French and Russian languages). Proc. of the 6th International Multidisciplinary Scientific Conference SGEM 2018, Vol. 5, Issue 3.6 (pp. 617-624). Sofia : STEF92 Technology Ltd.

Noiriel, G. (2007). À quoi sert "l'identité nationale? Marseille: Éditions Agone.

Pozner, V. V. (2013). Ikh Italiya [Their Italy]. Moscow : AST publ. House. (In Russian).

Rénan, E. (1887). Qu'est-ce qu'une nation? In E. Rénan (Ed.), Discours et conférences. (pp. 277-310). Paris : Calmann-Lévy.

Sternin, I. A., Larina, T. V., Sternina, M. A. (2003). Ocherk angliyskogo kommunikativnogo povedeniya [Essay of the English Communicative Behaviour]. Voronezh : Istoki Press. (In Russian).

Zheltova, N. Yu. (2003). Proza E. I. Zamyatina: puti khudozhestvennogo voploshcheniya russkogo natsional'nogo kharaktera [E. I. Zamyatin's prose: Methods of artistic embodiment of a Russian national character]. Tambov : Tambov State University Press. (In Russian).

Encyclopedia.com. The World's \#1 Online Encyclopedia. (2019). Oxford University Press; Columbia University Press; Cengage. Retrieved from <https://www.encyclopedia.com/medicine/ encyclopedias-almanacs-transcripts-and-maps/ethnic-identity>.

Lexico (2020). Oxford English and Spanish Dictionary, Thesaurus, and Spanish to English Translator. Retrieved August 5, 2020 from $<$ https://www.lexico.com/>.

Sotsiologiya: Entsiklopediya [Sociology: Encyclopedia]. (2020). Akademik [Academician]. Retrieved August 5, 2020 from <https://sociology_encyclopedy.academic.ru/>.

УДК 81'23

doi: 10.22250/2410-7190_2021_7_1_5_12

Авагян Асмик Арменовна

Российский государственный университет туризма и сервиса, Российский университет дружбы народов

Москва, Российская Федерация

avagyanasmik@gmail.com

Газилов Магомед Газилович, Гозалова Марина Робертовна

Российский государственный университет туризма и сервиса

Москва, Российская Федерация

mag.wizard@yandex.ru,mgozalova@mail.ru

\title{
Язык как форма выражения национальной идентичности: русский национальный характер в пословицах
}

\begin{abstract}
Аннотация
Статья содержит результаты анализа русских пословиц, отражающих некоторые распространённые стереотипные черты русского характера. Методология исследования включает в себя несколько этапов: выборка 400 русских пословиц и поговорок, иллюстрирующих различные стороны русского национального характера, количественный анализ собранного материала и тематическая группировка 30 пословиц,
\end{abstract}


наиболее ярко отражающих стереотипы о русском народе. В теоретической части статьи приводятся определения таких ключевых понятий, как «нация», «национальность», «этничность», «национальная, гражданская, этническая идентичность», которые были проанализированы с привлечением результатов предшествующих исследований в данном направлении. Результаты исследования показали, что наиболее распространённые черты характера русского народа - религиозность, терпение и решительность, трудолюбие и талант, свободолюбие, сила воли и смелость, гостеприимство, щедрость и широта души.

Ключевые слова: национальная идентичность, нация, русский язык, национальный характер, пословицы, поговорки.

(C) Авагян А. А., Газилов М. Г., Гозалова М. Р. 2021

Для цитирования: Avagyan A. A., Gazilov M. G., Gozalova M. R. Language as a form of expressing the national identity: A Russian national character in proverbs // Теоретическая и прикладная лингвистика. 2021. Вып. 7, № 1. С. 5-12. doi: 10.22250/2410-7190_2021_7_1_5_12.

\section{Список литературы}

Бадмаев, 2005 - Бадмаев В.Н. Феномен национальной идентичности (социально-философский анализ). Волгоград-Элиста: Калмыцкий институт социально-экономических и правовых исследований, 2005. 280 с.

Даль, 2000 - Даль В. И. Пословицы и поговорки русского народа. М. : Эксмо-Пресс, 2000. 608 с.

Delbecque, Richard, 2016 - Delbecque, E., Richard, S. L'identité nationale, tout le monde en parle, mais qu'est-ce que c'est? // Le Figaro/ 2016. URL: http://www.lefigaro.fr/vox/politique/ 2016/10/11/31001-20161011ARTFIG00305-1-identite-nationale-tout-le-monde-en-parle-mais-quest-ce-que-c-est.php.

Киселев, Смирнова, 2006 - Киселев И.Ю., Смирнова А.Г. Динамика образа государства в международных отношениях. СПб : Изд-во СПбГУ, 2006. 375 с.

Макарова и др., 2018 - Макарова А. И., Газилов М. Г., Гозалова М. Р. Проблема единства и разнообразия языковой картины мира (на основе сравнительного исследования идиоматических выражений французского и русского языков) [The issue of unity and diversity of linguistic worldview (on the basis of comparative research of idiomatic phrases of French and Russian languages)] // Материалы 6-й междунар. междисциплинарной науч. конф. SGEM 2018. T. 5 (3.6). София : STEF92 Technology Ltd, 2018. С. 617-624.

Noiriel, 2007 - Noiriel, G. À quoi sert "l'identité nationale"? Marseille : Éditions Agone, 2007. 154 p.

Познер, 2013 - Познер В. В. Их Италия. М. : АСТ, 2013. 320 с.

Rénan, 1887 - Rénan, E. Qu'est-ce qu'une nation? // Discours et conférences / Ed. by E. Rénan. Paris : Calmann-Lévy, 1887. P. 277-310.

Стернин и др., 2003 - Стернин И. А., Ларина Т. В., Стернина М. А. Очерк английского коммуникативного поведения. Воронеж : Изд-во «Истоки», 2003. $183 \mathrm{c.}$

Желтова, 2003 - Желтова Н. Ю. Проза Е. И. Замятина: пути художественного воплощения русского национального характера. Тамбов : Изд-во ТГУ, 2003. 184 с.

Encyclopedia.com, 2019 - Encyclopedia.com. The World's \#1 Online Encyclopedia. Oxford University Press; Columbia University Press; Cengage, 2019. URL: https://www.encyclopedia.com/ medicine/encyclopedias-almanacs-transcripts-and-maps/ethnic-identity.

Lexico, 2020 - Lexico. Oxford English and Spanish Dictionary, Thesaurus, and Spanish to English Translator. URL : https://www.lexico.com/ (дата обращения : 05.08.2020)

Социология, 2020 - Социология: Энциклопедия // Академик. URL: https:/ sociology_encyclopedy.academic.ru/ (дата обращения : 05.08.2020). 